\title{
Morphological Variability in Paleoanthropology: New Approaches, New Issues?
}

\section{La variabilité morphologique en paléoanthropologie : de nouvelles approches, de nouveaux enjeux ?}

\author{
G. Daver · A. Balzeau · G. Berillon · F. Guy
}

Reçu le 11 janvier 2019; accepté le 8 mars 2019

(C) Société d'Anthropologie de Paris et Lavoisier SAS 2019

Since Darwin's seminal works, variability—from which selection acts - is considered as being specific to populations. Variability or the propensity to vary differs from variation, which represents 'the actually realised differences between individuals' in a population/sample, or between species in a clade [1, p. 967]. Hence, variability is more complex to quantify than variation, and in general, biological anthropologists focus their efforts primarily on variation sensu stricto. In human and non-human primates, as in all other living organisms, the potential causes of morphological variation have multiple sources. However, two main types can be identified: genetic and environmental. Genetic sources of variation are produced via mutations, sexual reproduction, epigenetics or gene flow. Environmental sources include, for instance, the prenatal environment, nutrition, quality of life and health care, culture and climate. Other sources of variation are more specifically considered in evolutionary anthropology as exemplified by diachronic or phylogenetic variations. For example, over the last decade, palaeoanthropology has yielded several new hominin taxa/ groups based on morphological and genetic data (e.g. Denisova hominins [2], Homo gautengensis [3], Australopithecus sediba [4], new early representatives of the genus Homo [5], Homo naledi [6] and Australopithecus deyiremeda [7]).

\section{G. Daver $(\triangle) \cdot$ F. Guy}

PALEVOPRIM : laboratoire Paléontologie,

Évolution, Paléoécosystèmes, Paléoprimatologie,

UMR 7262, CNRS, université de Poitiers, Poitiers, France

e-mail : guillaume.daver@univ-poitiers.fr

A. Balzeau · G. Berillon

Équipe PaleoFED, UMR 7194 du CNRS,

département Homme et environnement,

Muséum national d'histoire naturelle, Paris, France

\section{A. Balzeau}

Department of African Zoology,

Royal Museum for Central Africa, Tervuren, Belgium
Taken as a whole, the above-mentioned sources of variation illustrate the need to take variations of a distinctive nature (genotypic, phenotypic) into account at varying scales of organisation (from a simple anatomical structure to an integrated system), within and among clades (i.e. extant and extinct taxa).

Despite this increasingly well-documented variation and numerous conceptual and methodological developments, anthropologists seem to be inevitably confronted with the difficulty of interpreting, and even compiling, such very large amounts of data. This is why we wanted to explore this topic in a special session of the $1843^{\text {rd }}$ SAP meeting, held in Poitiers, at the Espace Mendès-France, from 24 to 26 January 2018. Our guest speaker, Prof M. Bastir, introduced the special session and 21 papers were given, including 17 podium presentations and four poster displays. The six articles published in this issue of the BMSAP illustrate the diversity of the topics addressed during this session [8-13].

Five podium presentations and one poster display considered variation/variability in complex biological systems as a whole in terms of their different levels of organisation: introducing the session, Prof Bastir explored Neanderthal craniofacial morphology from the hierarchical and organism perspectives by integrating masticatory and respiratory biomechanics, ontogenetics and evolutionary morphological interactions between the central nervous system and the respiratory system, showing that integrative approaches yield a further understanding of the biological significance of specific features in hominin skeletal morphology [14]. For obvious reasons, such covariation analyses are still frequently applied to extant humans. For example, Albessard et al. highlighted similar spatial patterns of asymmetry between neurocrania and associated endocasts of 39 Homo sapiens, suggesting a close link between neurocranium asymmetry and brain

\footnotetext{
${ }^{1}$ Articles relating to this specific session were produced with the associated editors (G. Daver, A. Balzeau, G. Berillon and F. Guy).
} 
development [15]. Le Maitre and Mazurier emphasised the importance for bony labyrinth growth of the spatial constraints due to the shape of the petrosal bones in the cranium, a crucial point in any attempt to interpret the variation of such a structure from an ecological perspective [16]. In an attempt to better understand the correspondence between genotype and phenotype, Romeyer-Dherbey et al. compared the impacts of coronal nonsyndromic craniosynostosis on cranial shape in children, which made it possible to draw up a severity gradient and to consider setting up such analyses in new medical protocols [17]. By extension, the need to compare human variation/variability patterns with other patterns in non-human taxa is inherent to evolutionary studies and therefore to palaeoanthropology. Neaux et al. showed how morphological integration impacts shape disparity but not rates of phenotypic evolution, by demonstrating that the basicranium and face in primates are significantly integrated structures that can nevertheless also be considered as distinct modules, since both could evolve at different rates in response to different adaptive pressures [18]. From the postcranial perspective, Domalain et al. presented a realistic biomechanical simulation of hand force capability in fossil hominins and, as an example, demonstrated that the carpometacarpal joint of the fifth digit in Australopithecus could have been a factor limiting their ability to maintain Lomekwian-like tools [19].

The second set of presentations (four podium presentations, one poster display) focused on unravelling the formfunction relationships of specific bone structures in connection with ecological functions, in order to propose potential applications to the fossil record. The impact of locomotion was the object of particular attention in this respect. Colombo et al. presented a new method for quantifying the morphological signal associated with the acquisition of bipedalism in the trabecular architecture of the radii in children from 0 to 3 years of age [20]. Druelle et al. demonstrated that, during growth, morphological variations in the body segments of olive baboons from 0 to 8 years of age conform to a general pattern typical of catarrhine primates, but they also showed that some inertial segment properties change with the varying locomotor repertoire [21]. Apart from locomotion, masticatory functions were also discussed. Investigating relationships between the distribution of enamel thickness and diets of extant primates, Thiery et al. showed, for instance, that various morphological and behavioural strategies might have been selected in primates that consume stress-limited food [22]. Martin-Moya et al. tested the influence of environmental and cultural behaviour patterns on craniomandibular morphology, using early settlement of the Americas a framework [23]. They identified a high correlation between cranial and mandibular shapes, but also highlighted the impact of cultural diets on variation in mandibular shape. Like locomotion and diet, the functional foundations of childbirth are also of prime ecological interest.
Based on 131 extant dyads, Frémondière and Marchal supported that rotational birth likely have occurred with the emergence of the genus Homo, and suggest that such a physiological process may have been accompanied by the onset of a secondary altriciality and obstetrical assistance [24]

Finally, seven podium presentations and two poster displays proposed a reappraisal of morphological variation in extinct species based on new specimens and/or new approaches. Most concerned the difficulties of working out the perimeter of morphological variation in early hominins. Beaudet explained how new methodological developments (3D modelling) show that the endocast of Australopithecus africanus departs from the ancestral morphotype and pointed to unexpected degrees of variation in the spatial organisation of the frontal lobes of later hominins such as Homo erectusergaster and Homo heidelbergensis [25]. Daver et al. described three new limb bones (i.e. phalanx, proximal radius and second metatarsal) assigned to Paranthropus boisei (2.12 $\mathrm{Ma}$, Shungura Formation). Evidence of habitual bipedalism and a propensity for climbing supported by these remains has helped to gain a better understanding of morphofunctional variations in an as yet poorly documented hominin [26]. Cazenave presented a reappraisal of isolated postcranial bones from various South African sites classically assigned to Paranthropus robustus, where high-resolution computed tomography and 3D analyses identified contrasting signals between the external and inner morphology of some of these remains (e.g. patella, distal humerus) and close affinities with extant humans for others (femur) [27]. Souron and Boisserie addressed the question of the taxonomic status of the early African and Georgian representatives of the genus Homo [28]. Considering denthognatic remains from two populations of African bush pigs and their fossil relatives, they showed that extinct morphospecies might represent complexes of several biological species. Based on quantitative measurements of various traits of both taxonomic and adaptive interests (dental tissue proportions, topographic distribution of enamel thickness, enamel-dentine junction), Zanolli identified different morphological trends that distinguish Southeast Asian specimens (Java) from continental Middle Pleistocene humans [29]. In their exhaustive comparative analysis, Condemi et al. found that the 19 Neanderthal teeth identified at Vergisson II, like those from other Burgundian sites, share closer affinities with specimens from the Mediterranean basin and even from Northern and Western Europe than with specimens from the 'Near East' [30].

Two presentations focused on the recently created species Homo naledi, which provides a unique opportunity to assess morphological variation in a fossil human species, thanks to its exceptionally rich hypodigm. Based on a reappraisal of the endocrania and of some of their reconstructions, Balzeau and de Bruicker underlined the close morphological affinities of the species with early representatives of the genus 
Homo and Homo erectus [31]. Voisin et al. analysed the numerous remains of clavicles and scapulae from the cave chambers of Dinaledi and Lesedi and pointed to the intriguing combination of arboreal and bipedal behaviour suggested by the shoulder architecture and lower limb morphology in this geologically recent species [32]. In their study of the footprints from Rozel (Late Pleistocene, Manche, France), Duveau et al. presented an actualistic approach that involved recording 24 humans moving barefoot at various speeds on Rozel-like substrates: the authors demonstrated that different individuals ( $1-1.70 \mathrm{~m}$ in height) could have walked on the same surface of occupation [33]. Coutinho Nogueira et al. brought new insights into variations in Near Eastern Late Pleistocene humans through a reappraisal of age at death, developmental abnormalities and descriptions of the inner structures of the craniofacial remains of the Qafzeh 9 individual [34].

To summarise, this session showed that biological anthropologists have to deal with numerous sources of variation/ variability (phylogeny, development/ontogeny/growth, genetics, behaviour, ecology, environment, sexual dimorphism, geography, idiosyncratic variation) to which many different fields are contributing, including palaeontology, primatology, palaeopathology, ontogeny and biomechanics. Whatever the sources, variations in complex biological systems occur at different levels of organisation (from individual organisms, species or populations to the ecological or community level), but the transmission of variation from one level to the next is neither straightforward nor intuitive [35]. This is why any source of variation in a biological system should be investigated further from an integrative or transdisciplinary perspective. There is now, more than ever, a need for such a holistic approach, and the many fascinating presentations we heard during this SAP meeting at Poitiers testify to the vitality of current research on this topic.

\section{References}

1. Wagner GP, Altenberg L (1996) Perspective: complex adaptations and the evolution of evolvability. Evolution 50:967-76

2. Krause J, Fu Q, Good JM, et al (2010) The complete mitochondrial DNA genome of an unknown hominin from southern Siberia. Nature 464:894-7

3. Curnoe D (2010) A review of early Homo in southern Africa focusing on cranial, mandibular and dental remains, with the description of a new species (Homo gautengensis sp. nov.). HOMO 61:151-77

4. Berger LR, de Ruiter DJ, Churchill SE, et al (2010) Australopithecus sediba: a new species of Homo-like australopith from South Africa. Science 328:195-204

5. Villmoare B, Kimbel WH, Seyoum C, et al (2015) Paleoanthropology. Early Homo at 2.8 Ma from Ledi-Geraru, Afar, Ethiopia. Science 347:1352-5
6. Berger LR, Hawks J, de Ruiter DJ, et al (2015). Homo naledi, a new species of the genus Homo from the Dinaledi Chamber, South Africa. Elife 4:e09560

7. Haile-Selassie Y, Gibert L, Melillo SM, et al (2015) New species from Ethiopia further expands Middle Pliocene hominin diversity. Nature $521: 483-8$

8. Bastir M (2019) Big choanae, larger face: scaling patterns between cranial airways in modern humans and African apes and their significance in Middle and Late Pleistocene hominin facial evolution. BMSAP 31(1-2):9-13

9. Buck LT, Stringer CB, MacLarnon AM, Rae TC (2019) Variation in paranasal pneumatisation between Mid-Late Pleistocene hominins. BMSAP 31(1-2):14-33

10. Le Maitre A (2019) Role of spatial integration in the morphology of the bony labyrinth in modern humans. BMSAP 31(1-2):34-42

11. Colombo A, Stephens NB, Tsegai ZJ, et al (2019) Trabecular analysis of the distal radial metaphysis during the acquisition of crawling and bipedal walking in childhood: a preliminary study. BMSAP 31(1-2):43-51

12. Thiery G, Guy F, Lazzari V (2019) Enamel 3D distribution: is enamel more unevenly thick in upper second molars of durophagous hominoids? BMSAP 31(1-2):52-9

13. Jovanović J, Frémondière P, Stefanović S (2019) Reconstruction of two mother-infant dyads and obstetrical consequences of the Mesolithic-Neolithic transition: a case study from Lepenski Vir and Vlasac (Serbia). BMSAP 31:(1-2):60-8

14. Bastir M (2018) The significance of the respiratory system for cranial and postcranial skeletal morphology in Neanderthals and modern humans. BMSAP 30(S1):S9

15. Albessard L, Kitchell L, Grimaud-Hervé D, et al (2018) Une comparaison des asymmétries crâniennes et endocrâniennes chez Homo sapiens. BMSAP 30:S10

16. Le Maître A, Mazurier A (2018) Étude préliminaire des covariations morphologiques entre le labyrinthe osseux et la base du crâne chez Homo sapiens. BMSAP 30(S1):S18-9

17. Romeyer Dherbey J, Di Rocco F, Legeai-Mallet L, et al (2018) Quantification de la variation morphologique crânienne au sein d'un échantillon d'enfants atteints de craniosynostoses de la suture coronale. BMSAP 30(S1):S26

18. Neaux D, Sansalone G, Ledogar JA, et al (2018) Basicranium and face: assessing the impact of morphological integration on primate evolution. BMSAP 30(S1):S22-S3

19. Domalain M, Bertin A, Daver G (2018) Développement d'une simulation biomécanique des capacités de forces de préhension d'homininés fossiles et nouvelles perspectives sur l'implication du cinquième doigt. BMSAP 30(S1):S15

20. Colombo A, Stephens N, Tsegai ZJ, Bettuzzi M, Morigi MP, Belcastro MG, Hublin J-J (2018) Analyse micro-architecturale du développement de la marche bipède chez le jeune enfant : résultats préliminaires. BMSAP 30(S1):S13

21. Druelle F, Aerts P, D'Août K, et al (2018) Variation morphologique au cours de l'ontogenèse chez les primates actuels : modèles généraux et différences interspécifiques. BMSAP 30(S1):S15

22. Thiery G, Lazzari V, Ramdarshan A, Guy F (2018) La distribution de l'émail permet-elle de déduire la capacité à consommer des aliments durs ? Apport de l'étude de la topographie dentaire 3d des anthropoïdes actuels. BMSAP 30(S1):S29

23. Martin-Moya D, Galland M, Friess M (2018) Les premiers peuplements de l'Amérique, influence des facteurs environnementaux et culturels sur la variabilité morphologique mandibulaire et crânienne. BMSAP 30(S1):S20

24. Frémondière P, Marchal $F$ (2018) La rotation intra-pelvienne, explications obstétricales et enjeux évolutifs. BMSAP 30(S1):S16

25. Beaudet A (2018) Comment reconstruire l'histoire évolutive du cerveau hominine à partir du registre fossile ? Limites et perspectives en paléoneurologie humaine. BMSAP 30(S1):S11 
26. Daver G, Berillon G, Jacquier C, et al (2018) Nouveaux restes postcrâniens d'Homininés de la localité OMO 323, Formation de Shungura, Basse Vallée de l'Omo, Sud-Ouest de l'Éthiopie. BMSAP 30(S1):S14-S5

27. Cazenave M (2018) Caractéristiques endostructurales du squelette postcrânien de Paranthropus robustus. Implications taxinomiques, fonctionnelles et paléobiologiques. BMSAP 30(S1):S13

28. Souron A, Boisserie JR (2018) Est-ce que des espèces proches parentes et morphologiquement ressemblantes sont identifiables dans le registre fossile? Implications d'une étude de la variabilité crâniomandibulaire et dentaire chez les porcs à pinceaux actuels (Mammalia: Suidae: Potamochoerus). BMSAP 30(S1):S28

29. Zanolli C (2018) La variation endostructurale des dents homininées d'Asie au Pléistocène inférieur et moyen. BMSAP 30(S1): S30-S1

30. Condemi S, Giuliani ME, Saliba-Serre B, et al (2018) Les dents néandertaliennes de Vergisson II. BMSAP 30(S1):S13-S4
31. Balzeau A, de Bruicker LL (2018) Paléoanthropologie et variabilité du cerveau, que dire d'Homo naledi ? BMSAP 30(S1):S11

32. Voisin JL, Feuerriegel EM, Churchill SE, et al (2018) La ceinture scapulaire d'Homo naledi. BMSAP 30(S1):S30

33. Duveau J, Berillon G, Biets C, et al (2018) Variation morphologique d'empreintes de pieds et substrat : apport de l'expérimentation à la connaissance de la biologie des hommes du Rozel (Pléistocène supérieur, Manche). BMSAP 30(S1):S16

34. Coutinho Nogueira D, Coqueugniot H, Tillier AM (2018) La microtomodensitométrie, nouvel outil d'analyse de fossiles humains anciennement découverts : l'exemple de Qafzeh 9. BMSAP 30(S1):S14

35. Hallgrímson B, Hall BK (2005) Variation and variability: Central concepts in biology. In: Hallgrímsson B, Hall BK (eds) Variation: a central concept in biology. Academic Press, Cambridge, MA, pp 1-7 